\title{
Türkçe öğretmeni adaylarının dijital hikâyeye yönelik metaforik algıları
}

\section{Aysun EROĞLU1}

\begin{abstract}
APA: Eroğlu, A. (2020). Türkçe öğretmeni adaylarının dijital hikâyeye yönelik metaforik algıları. RumeliDE Dil ve Edebiyat Araşttrmalar Dergisi, (18), 49-6o. DOI: 10.2900o/rumelide.705506.
\end{abstract}

\section{$\ddot{\mathbf{O z}}$}

$\mathrm{Bu}$ çalışmanın amacı, Türkçe öğretmeni adaylarının dijital hikâyelerle ilgili algılarını metaforlar yoluyla ortaya çıkarmaktır. Bu amaç doğrultusunda, bu çalışmada nitel araştırma yöntemlerinden olgu bilim (fenomenoloji) kullanılmıştır. Kafkas Üniversitesi Eğitim Fakültesi Türkçe Eğitimi Ana Bilim Dalı'nda 3. ve 4. sınıf düzeyinde öğrenim gören toplam 77 öğretmen adayı ile çalışma yürütülmüştür. Veriler, öğretmen adayları için hazırlanan metafor formu ile toplanmış ve analiz için de içerik analizi kullanılmıştır. Araştırmanın geçerlik ve güvenirliğini sağlamak için araştırmacı ve iki uzman değerlendirme toplantısı yapmıştır. Araştırmacı, sözel olarak tüm süreci ve sonuçları uzmanlarla paylaşmış ve uzmanların süreçle ilgili sorularını cevaplamıştır. Ayrıca, metaforların sınıflandırılması konusunda uzmanların görüşü alınmıştır. Araştırmanın sonucunda, 77 Türkçe öğretmeni adayının dijital hikâye algılarını ortaya çıkaran 9 metafor kategorisi (eğlence, eğitim, yaşam, güvensiz bulma, evren ve gökyüzü, doğa, teknoloji, fayda bulma ve yiyecek) bulunmuştur. Öğretmen adaylarının en çok (15 metafor) eğlence kategorisinde metafor oluşturdukları ve oluşturulan bu metaforların daha çok erkek öğrenciler tarafindan oluşturulduğu görülmüşsür. Öğretmen adaylarının eğitim, teknoloji ve faydalı bulma kategorilerinde toplam 23 metafor oluşturdukları ve bu metaforların daha çok akıllı cep telefonu ve bilgisayarı olan öğrenciler tarafından oluşturulduğu görülmüştür. Öğretmen adaylarının oluşturdukları diğer metafor kategorilerine bakıldığında ise yaşam, evren ve gökyüzü, doğa ve yiyecek kategorilerinde toplam 30, güvensiz bulma kategorisi altında ise 9 metafor oluşturdukları görülmüştür.

Anahtar kelimeler: Dijital hikâye, metafor, Türkçe öğretmeni adayları, olgu bilim.

\section{Metaforic perceptions of prospective Turkish teachers for digital story}

\begin{abstract}
The aim of this study is to reveal the perception of prospective Turkish teachers about digital stories through metaphors. In this study, phenomenology, one of the qualitative research methods, was used. This study was conducted with 77 prospective teachers from 3rd and 4th grades studying at the department of Turkish Education in Faculty of Dede Korkurt Education of Kafkas University. The data were collected with metaphor form prepared for prospective teachers and content analysis was used. To ensure the validity and reliability of the research, researcher and two experts held evaluation meeting. Researcher shared the whole process and results with experts and answered the experts' questions about the process. The researcher took the opinion of experts on the classification of metaphors. As a result of the research, 9 metaphor categories (entertainment, education, life, insecure, universe and sky, nature, technology, beneficial and food) were found. The most metaphors (15 metaphors) created by male prospective teachers are metaphors of the entertainment category.
\end{abstract}

1 Arş. Gör., Kafkas Üniversitesi, Eğitim Fakültesi, Türkçe ve Sosyal Bilimler Eğitimi Bölümü, Türkçe Eğitimi ABD (Kars, Türkiye); Doktora Öğrencisi, Sakarya Üniversitesi, Eğitim Bilimleri Enstitüsü, Türkçe Eğitimi Bilim Dalı (Sakarya, Türkiye), 24aysun@gmail.com, ORCID ID: 000o-0003-1047-8748 [Makale kaytt tarihi: 27.12.2019-kabul tarihi: 20.03.2020; DOI: 10.29000/rumelide.705506] 
It was seen that prospective teachers formed 23 metaphors in education, technology and beneficial categories and these metaphors were mostly formed by students who have smart phones and computers. Prospective teachers created 30 metaphors in life, universe and sky, nature and food categories. There are 9 metaphors in insecure category.

Keywords: Digital story, metaphor, prospective Turkish teachers, phenomenology.

\section{Giriş}

21. yüzyılda, hızlı teknolojik gelişmelerle beraber çoğu alanda dijitalleşme olmuştur. Dijital kütüphane, dijital oyun, dijital okuryazarlık gibi çoğu alanda günümüz koşullarına ayak uydurma söz konusudur. Dijitalleşen dünyaya uzak kalmayan bir başka alan da hikâyelerdir: Dijital hikâyeler. Hikâye bir olayın sözlü veya yazılı olarak anlatılması, gerçek veya tasarlanmış olayları aktaran (TDK, 2011; Doğan, 2005; Akbayır, 2007; Babacan, 2008) bir metin türüdür. Hikâye metin türü olarak 1-8. sinıfların tümünde mevcuttur (MEB, 2019). Hikâyeler, çocukların anlama ve anlatma becerilerine katkı sağlamakta ve sözcük dağarcığını geliştirmektedir (Temizyürek, 2003; Walsh ve Blewitt, 2006). Dijital hikâye ise hikâye ile resim, ses ve video gibi çoklu ortam ögelerinin birleştirilmesi fikrine dayanmaktadır (Robin, 2006; Alexandar, 2011). Frazel (2010)'e göre dijital hikâyeler ile öğrenciler yaratıcıklarını, işbirlikçi öğrenmelerini ve teknolojik becerilerini geliştiren çoklu ortam sunumlarını oluşturmak için müzik, ses efektleri, video ve daha fazlasından yararlanabilirler. Hett (2012)'e göre de yeni nesil hikâye anlatımı dijital hikâyelerin aracılığıyla başlamakta ve bu dijital hikâyeler, resimler, müzikler, ses dosyaları ile desteklenip bilgisayarda oluşturulmaktadır. Robin (2006)'e göre dijital hikâyelerde bulunması gereken yedi ögeden bahsedilebilir: Bakış açısı, çarpıcı bir soru, duygusal içerik, sesinizin verdiği armağan, film müziğinin gücü, ekonomiklik ve hız. Dijital hikâye oluşturma süreci ise Barrett (2009)'e göre 400 kelimelik bir hikâye metni yazıp seslendirmeyle başlamaktadır. Akabinde de uygun görseller ve müzikle desteklenip dijital hikâye halini almalıdır.

Metafor, bireyin kendi dünyasını anlamasına ve yapılandırmasına yönelik zihinsel haritalar ve modellerdir (Arslan ve Bayrakcı, 2006). Metafor, eğitim bilimleri alanında ise kavramların analiz edilmesinde, hayatın daha anlaşlır bir duruma getirilmesinde, deneyimlerin aktarılmasında, duygu ve düşüncelerin paylaşılmasında, bireyin bir nesne, kavram veya olguya dair algilarının belirlenmesinde kullanılmaktadır (Aykaç ve Çelik, 2014). Kısaca ise metafor iki benzeşmez olgu arasında ilişki kurmaya yardım eder (Saban, 2008). Bu çalışmada metafor kullanılmasının sebebi ise; metaforların öğretmen yetiştirme programlarındaki mesleki bilgileri daha anlaşılır ifadelerle anlamak ve anlatmak için de tercih edilebilir olmasıdır (Dündar ve Karaca, 2013).

Türkçe öğretmeni adaylarıyla yapılan metafor çalışmalarına bakıldığında ise; okuma kavramı (Erdağı Toksun, 2019; Karakuş ve Kozçetin, 2016), ekrandan okuma (Azizoğlu ve Okur, 2018), öğretmen ve öğrenci kavramı (Seçkin Aydın ve Pehlivan, 2010), dört temel dil becerisi (Bozpolat, 2015), kültür dil ilişkisi (Göçer, 2013), yazma becerisi (Tiryaki ve Demir, 2016), eleştirel yazma (Topçuoğlu Ünal ve Tekin, 2013), Türkçe ders kitapları (Ceran, 2015), bilgi ve kitap (Polatcan, 2018) üzerine çalışıldığı görülmüştür.

Dijital hikâye anlatımıyla ilgili çalışmalara bakıldığında, dijital hikâye anlatımını içeren seminer sonrası gelişimlerin takibi (Dogan, 2007; Gordon, 2011; Tatlı ve Bayramoğlu, 2015), dijital hikâyenin öğrencilerin akademik başarılarına, motivasyonlarına, problem çözme becerilerine, algılarına, derse yönelik tutumlarına, teknoloji kullanma becerilerine, yazma becerilerine, hikâye yazma becerilerine, 
yabancı dil öğrenme becerilerine, Türkçe öğrenme becerilerine (Wang ve Zhan, 2010; Hung, Hwang ve Huang, 2012; Yoon, 2013; Yürük ve Atıcı, 2016; Yamaç ve Ulusoy, 2016; Kaya ve Tolu, 2017; Yılmaz, Üstündă̆, Güneş ve Çalışkan, 2017) etkisinin araştıııldığı ve rubrik geliştirme (Çıralı Sarıca ve Koçak Usluel, 2016) çalışması yapıldığı görülmüştür.

Dijital hikâye anlatımı, ilk olarak Berkeley'de sanatsal bir organizasyonda 1980'lerin sonunda görülmüş ve 1998 yllında Dijital Hikâye Anlatım Merkezi (Center For Dijital Storytelling-CDS) kurulmuştur. Yakın bir geçmişi olan dijital hikâyelerin eğitim-öğretim ortamlarında kullanılmaya başladığı, eğitime yansımalarının araştırılmaya başlandığı görülmüştür (Dayan ve Girmen, 2018; Abou Shaaban, 2015; Baki, 2015; Yamaç, 2015; Ciğerci 2015; Karakoyun, 2014; Göçen, 2014; Çıralı, 2014; Demirer, 2013; Kahraman, 2013; Foley, 2013; Gordon, 2011; Yüksel, 2011; Dogan, 2007; Banaszewski, 2005;). Bu araştırmanın amacı, Türkçe öğretmeni adaylarının güncel bir çalışma alanı olan dijital hikâyelerle ilgili algılarını metaforlar yoluyla ortaya çıkarmaktır. 21. yüzyıl becerilerini edinebilmiş öğrencileri yetiştirmeyi amaçlayan öğretmenlerin niteliğini arttırmaya yönelik araştırmalara, bu çalışmanın yardımcı olacağı düşünülmektedir.

\section{Yöntem}

$\mathrm{Bu}$ çalışmada, nitel araştırma yöntemlerinden olgu bilim (fenomenoloji) kullanılmıştır. Olgu bilim, farkında olduğumuz ancak derinlemesine ve ayrıntılı bir anlayışa sahip olmadığımız olgulara odaklanmakta ve olgular, yaşadığımız dünyada olaylar, deneyimler, algılar, yönelimler, kavramlar ve durumlar gibi farklı biçimlerde karşımıza çıkmaktadır (Yıldırım ve Şimşek, 2013).

\section{Çalışma grubu}

$\mathrm{Bu}$ araştırmanın çalışma grubu, 2019-2020 eğitim-öğretim ylından Kafkas Üniversitesi Eğitim Fakültesi Türkçe Eğitimi Ana Bilim Dalı’nda öğrenim gören 77 öğretmen adayından oluşmaktadır. 39 öğretmen adayı 4. sınıf öğrencisi, 38 öğretmen adayı ise 3. sınıf öğrencidir.

Bu araştırmanın çalışma grubu, amaçlı örnekleme yöntemlerinden kolay ulaşlabilir durum örneklemesi kullanılarak oluşturulmuştur. Çünkü bu örnekleme ile araştırmaya hız ve pratiklik kazandırılmaktadır (Ylldırım ve Şimşek, 2013).

\section{Veri toplama aracı ve verilerin toplanması}

Veriler, öğretmen adayları için hazırlanan metafor formu ile elde edilmiştir. Araştırma verileri, öğretmen adaylarının oluşturduğu metaforlardır. Metaforlar, insanın doğayı ve çevreyi anlamasını, anlamsız gibi görünen nesnel gerçeklikten belirli yorumlar yoluyla anlamlar çıkarmasını, yaşantı ve deneyime anlam kazandırmanın araçları olarak bilmeyi mümkün kılar (Yıldırım ve Şimşek, 2013).

Verilerin toplanması için oluşturulan metafor formunda, yönerge kısmı, demografik bilgiler kısmı ve metafor kısmı bulunmaktadır. Yönerge kısmında, çalışmanın amacı belirtilip paylaşılan bilgilerin gizli kalacağı ve çalışma sonucunu merak edenler için mail adresi yazılmıştır. Demografik bilgiler kısmında, öğrencilerden cinsiyet, sınıf, akıllı cep telefonu ve bilgisayar sahibi olup olmadıklarını yazmaları istenmiştir. Metafor kısmında ise "Dijital Hikâye Çünkü .." ifadesini benzetme yaparak doldurmaları istenmiştir. 


\section{Verilerin analizi}

$\mathrm{Bu}$ araştırmada, içerik analizi kullanılmıştır. İçerik analizinde temel amaç, elde edilen verileri açılayabilecek kavramlara ve ilişkilere ulaşmak, benzer verileri belli kavramlar ve temalar çerçevesinde bir araya getirmek ve bunları anlaşılabilir olacak şekilde düzenleyerek yorumlamaktır (Yıldırım ve Şimşek, 2013). Bu doğrultuda öğretmen adaylarının oluşturdukları metaforlar incelenmiş, ortak özelliklere sahip metaforlar belirlenip sınıflandırılmıştır.

\section{Geçerlik ve güvenirlik}

Nitel araştırmalarda geçerlik ve güvenirliği sağlama yollarından biri uzman görüşü almaktadır. Yıldırım ve Şimşek (2013)'e göre uzman incelemesi iki şekilde yapılmaktadır. Birincisi araştırmacı ve uzmanın birlikte değerlendirme toplantısı yapması, ikincisi de araştırmacının elde ettiği tüm dokümanları ham haliyle bir uzmana göndermesidir. Bu araştırmada, araştırmacı ve iki uzman değerlendirme toplantısı yapmıştır. Araştırmacı, sözel olarak tüm süreci ve sonuçları uzmanlarla paylaşmıştır. Metaforların sınıflandırılması konusunda uzmanların görüşünü almıştır. Araştırmacı, uzmanların süreçle ilgili sorularını cevaplamıştır.

\section{Bulgular}

Öğretmen adaylarının dijital hikâye kavramına ilişkin oluşturdukları metaforlar eğlence, eğitim, yaşam, güvensiz bulma, evren ve gökyüzü, doğa, teknoloji, fayda bulma ve yiyecek olarak sınıflandırılmıştır.

\section{Eğlence kategorisine ait metaforlar}

Öğretmen adaylarının eğlence kategorisi çerçevesinde oluşturdukları metaforlar Tablo 1'de bulunmaktadır.

Tablo 1. Eğlence kategorisine ait metaforlar

\begin{tabular}{ll}
\hline Metafor & Siklık \\
\hline Film & 3 \\
Çizgi film & 2 \\
Müzik kutusu & 1 \\
Eğlence merkezi & 1 \\
Lunapark & 1 \\
Dizi & 1 \\
Sörf yapmak & 1 \\
Resim & 1 \\
Renkler & 1 \\
Bisiklet & 1 \\
Aşk & 1 \\
Serüven & 1 \\
Toplam & 15 \\
\hline
\end{tabular}


Tablo 1'de öğretmen adaylarının eğlence kategorisine ait metaforları bulunmaktadır. Bu kategoride en çok film ve çizgi film benzetmesi yaptıkları görülmektedir. Bunun dışında müzik kutusu, eğlence merkezi, lunapark, dizi, sörf yapmak, resim, renkler, bisiklet, aşk ve serüven benzetmesi yaptıkları görülmektedir.

K53 "Dijital hikâye eğlence merkezi gibidir. Çünkü birçok eğlenceli şey bir aradadır."

K65 "Dijital hikâye film gibidir. Çünkü oluşturulma aşaması benzer ve bazen kendi hayatımızdan bir parça buluruz."

\section{Ĕgitim kategorisine ait metaforlar}

Öğretmen adaylarının eğitim kategorisi çerçevesinde oluşturdukları metaforlar Tablo 2'de bulunmaktadir.

Tablo 2. Eğitim kategorisine ait metaforlar

\begin{tabular}{ll}
\hline Metafor & S1klık \\
\hline Kitap & 2 \\
Şermin kitabı & 2 \\
Eğitici/Öğretici & 2 \\
e-Kitap & 1 \\
Kurs & 1 \\
Bilgi & 1 \\
Toplam & 9 \\
\hline
\end{tabular}

Tablo 2'de öğretmen adaylarının eğitim kategorisine ait metaforları bulunmaktadır. Bu kategoride en çok kitap, Şermin kitabı ve eğitici/öğretici benzetmesi yaptıkları görülmektedir. Bunun dışında e-kitap, kurs ve bilgi benzetmesi yaptıkları görülmektedir.

K3 "Dijital hikâye e-kitap gibidir. Çünkü ikisinde de ekrana bakarız ve yeni bir şeyler öğreniriz."

K8 "Dijital hikâye kitap gibidir. Çünkü kitaptan bir şey öğrenebildiğimiz gibi dijital hikayelerden de öğrenebiliriz."

\section{Yaşam kategorisine ait metaforlar}

Öğretmen adaylarının yaşam kategorisi çerçevesinde oluşturdukları metaforlar Tablo 3'te bulunmaktadir.

Tablo 3. Yaşam kategorisine ait metaforlar

\begin{tabular}{ll}
\hline Metafor & Slklık \\
\hline Hayat & 5 \\
Hayatın kendisi & 1 \\
Gerçek & 1 \\
Yaşamdan bir parça & 1 \\
Ölmüş insan & 1 \\
Toplam & 9 \\
\hline
\end{tabular}


Tablo 3'te öğretmen adaylarının yaşam kategorisine ait metaforları bulunmaktadır. Bu kategoride en çok hayat benzetmesi yaptıkları görülmektedir. Bunun dışında gerçek, yaşamdan bir parça ve ölmüş insan benzetmesi yaptıkları görülmektedir.

K2 "Dijital hikâye hayat gibidir. Çünkü hayatımızda olan olaylar, sesler, görseller bir bütün olduğu gibi dijital hikayenin de anlattığı içerikler sesler ve görsellerle bir bütün oluşturuyor.”

K67 "Dijital hikâye hayatın kendisi gibidir. Çünkü hayatın bize ders verdiği gibi dijital hikayeler de bize bir şey öğretir. Hayat gibi çok duyuya hitap ettiği için unutması zor olur.”

\section{Güvensiz bulma kategorisine ait metaforlar}

Öğretmen adaylarının güvensiz bulma kategorisi çerçevesinde oluşturdukları metaforlar Tablo 4’te bulunmaktadır.

Tablo 4. Güvensiz bulma kategorisine ait metaforlar

\begin{tabular}{lc}
\hline Metafor & S1klık \\
\hline Hayal & 2 \\
Zaman & 2 \\
Kumar & 1 \\
Işı̆̆l kendini aydınlatmayan kandil & 1 \\
Çaylaklık & 1 \\
Pire & 1 \\
Virüs & 1 \\
Toplam & 1 \\
\hline
\end{tabular}

Tablo 4'te öğretmen adaylarının güvensiz bulma kategorisine ait metaforları bulunmaktadır. Bu kategoride en çok hayal ve zaman benzetmesi yaptıkları görülmektedir. Bunun dışında kumar, ışı̆̆ı kendini aydınlatmayan kandil, çaylaklık, pire ve virüs benzetmesi yaptıkları görülmektedir.

K46 "Dijital hikâye zaman gibidir. Çünkü zamanın nasıl geçtiğini anlamadığımız gibi dijital hikayeleri izlerken bittiğini anlamıyoruz."

K48 "Dijital hikâye hayal gibidir. Çünkü hayal kurmak güzeldir, dijital hikaye oluşturmak da güzeldir ama hayallerimiz her zaman gerçekleşmez, dijital hikayeler de her zaman istediğimiz gibi olmazlar.”

\section{Evren ve gökyüzü kategorisine ait metaforlar}

Öğretmen adaylarının evren ve gökyüzü kategorisi çerçevesinde oluşturdukları metaforlar Tablo 5’te bulunmaktadır.

Tablo 5. Evren ve gökyüzü kategorisine ait metaforlar

\begin{tabular}{ll}
\hline Metafor & S1klık \\
\hline Gökyüzü & 3 \\
Gökkuşağı & 2 \\
Uzay & 1 \\
Galaksi & 1 \\
Dünya & 1 \\
\hline
\end{tabular}




Toplam 8

Tablo 5’te öğretmen adaylarının evren ve gökyüzü kategorisine ait metaforları bulunmaktadır. Bu kategoride dijital hikâyeyi en çok gökyüzüne ve gökkuşağına benzettikleri görülmektedir. Ayrıca, uzay, galaksi ve dünya benzetmeleri yaptıkları da görülmektedir.

K23 "Dijital hikâye galaksi gibidir. Çünkü birçok gök cismi bir araya gelerek galaksiyi oluşturuyor. Dijital hikâyede de metin, müzik, fotoğraf gibi şeyler bir araya geliyor."

K63 "Dijital hikâye gökkuşağı gibidir. Çünkü gökkuşağındaki renkler gibi dijital hikâyede birçok şey vardır. Görüntü, ses, müzik, yazı, efekt... bu yüzden renkli ve eğlencelidir.”

\section{Doğa kategorisine ait metaforlar}

Öğretmen adaylarının doğa kategorisi çerçevesinde oluşturdukları metaforlar Tablo 6'da bulunmaktadır.

Tablo 6. Doğa kategorisine ait metaforlar

\begin{tabular}{ll}
\hline Metafor & Siklı \\
\hline $\mathrm{Su}$ & 6 \\
Doğa & 1 \\
Deniz & 1 \\
Toplam & 8 \\
\hline
\end{tabular}

Tablo 6'da öğretmen adaylarının doğa kategorisine ait metaforları bulunmaktadır. Bu kategoride en çok su benzetmesi yaptıkları görülmektedir. Bunun dışında doğa ve deniz benzetmesi de yapmışlardır.

K26 "Dijital hikâye su gibidir. Çünkü su nasıl akıyorsa dijital hikaye de öyle güzel akıp gidiyor. Sürükleniyorsun."

K74 “Dijital hikâye su gibidir. Çünkü akıcı ve rahattır. Bizi yormadan düşündürür.”

\section{Teknoloji kategorisine ait metaforlar}

Öğretmen adaylarının teknoloji kategorisi çerçevesinde oluşturdukları metaforlar Tablo 7'de bulunmaktadır.

Tablo 7. Teknoloji kategorisine ait metaforlar

\begin{tabular}{ll}
\hline Metafor & S1klık \\
\hline Bilgisayar & 2 \\
MP3 çalar & 1 \\
Simülasyon & 1 \\
Bağımlılık & 1 \\
Yapay zekâ & 1 \\
CD & 1 \\
Toplam & 7 \\
\hline
\end{tabular}


Tablo 7'de öğretmen adaylarının teknoloji kategorisine ait metaforları bulunmaktadır. Bu kategoride en çok bilgisayar benzetmesi yaptıkları görülmektedir. Bunun dışında mp3 çalar, simülasyon, bağımlılık, yapay zekâ ve cd benzetmesi de yapmışlardır.

K11 "Dijital hikâye cd gibidir. Çünkü her dinlediğimizde daha kalıcı öğrenme oluyor. Dijital hikayeyi de sürekli dinleyip izlersek konusunu daha iyi öğrenmiş oluruz."

K52 "Dijital hikâye simülasyon gibidir. Çünkü simülasyonda sanki gerçekte yaşıyormuşum gibi sürükleniyorum. Dijital hikaye de bana aynısını hissettiriyor."

\section{Faydalı bulma kategorisine ait metaforlar}

Öğretmen adaylarının faydalı bulma kategorisi çerçevesinde oluşturdukları metaforlar Tablo 8'de bulunmaktadır.

Tablo 8. Faydalı bulma kategorisine ait metaforlar

\begin{tabular}{ll}
\hline Metafor & Slklı \\
\hline Sonsuzluk & 2 \\
Dinleti & 1 \\
Kalıcı iş & 1 \\
Yatırım & 1 \\
Güven & 1 \\
İlaç & 1 \\
Toplam & 7 \\
\hline
\end{tabular}

Tablo 8'de öğretmen adaylarının faydalı bulma kategorisine ait metaforları bulunmaktadır. Bu kategoride en çok sonsuzluk benzetmesi yaptıkları görülmektedir. Bunun dışında dinleti, kalıcı iş, yatırım, güven ve ilaç benzetmesi de yapmışlardır.

K47 "Dijital hikâye yatırım gibidir. Çünkü maddi ya da manevi yatırım yapmak kaygılarımızı azaltır. Dijital hikaye izleyip bir şeyler öğrenmek de öyle.”

K24 "Dijital hikâye ilaç gibidir. Çünkü ilaçlarlar bizim iyileşmemize yardım eder, dijital hikaye bizi bilgi verir. Yani iki de faydalıdır."

\section{Yiyecek kategorisine ait metaforlar}

Öğretmen adaylarının faydalı bulma kategorisi çerçevesinde oluşturdukları metaforlar Tablo 9'da bulunmaktadir.

Tablo 9. Yiyecek kategorisine ait metaforlar

\begin{tabular}{ll}
\hline Metafor & Sıklık \\
\hline Sarma & 1 \\
Ayva & 1 \\
Sütlaç & 1 \\
Tuzsuz yemek & 1 \\
İçi bozuk meyve & 1 \\
Toplam & 5 \\
\hline
\end{tabular}


Tablo 9'a öğretmen adaylarının yiyecek kategorisine ait metaforları bulunmaktadır. Bu kategoride sarma, ayva, sütlaç, tuzsuz yemek ve içi bozuk meyve benzetmesi yaptıkları görülmektedir.

K9 "Dijital hikâye tuzsuz yemek gibidir. Çünkü tadı tuzu yoktur, dijital hikaye de öyle, tadsız tuzsuz sanal bir şey.”

K27 "Dijital hikâye içi bozuk meyve gibidir. Çünkü dıştan güzel görünen şeylerin içi güzel olmaz bazen. Dijital hikaye izlerken güzel ama oluşturması zor gibi.”

\section{Sonuç, tartışma ve öneriler}

$\mathrm{Bu}$ araştırma sonucunda, 77 Türkçe öğretmeni adayının dijital hikâye algılarını ortaya çıkaran 9 metafor kategorisi (eğlence, eğitim, yaşam, güvensiz bulma, evren ve gökyüzü, doğa, teknoloji, fayda bulma ve yiyecek) bulunmuştur. Öğretmen adaylarının en çok (15 metafor) eğlence kategorisinde metafor oluşturdukları ve oluşturulan bu metaforların daha çok erkek öğrenciler tarafindan oluşturulduğu görülmüştür. Dijital hikâyelerin hikâye anlatımını zenginleştiren resim ve fotoğraf gibi çeşitli görseller, ses ve müzik gibi çeşitli işitsel ögelerle desteklenmesi (Robin, 2006; Barrett, 2009; Frazel, 2010; Alexandar, 2011; Hett, 2012) hikâyeleri daha dikkat çekici ve eğlenceli kılmaktadır. Dijital hikâyelerin bilgisayar ortamında hazırlanması, 21. yüzyıl çocuklarının eğlence anlayışlarından biri olan bilgisayar ekranı üzerinde oluşturulması ve sunulmasının etkili olduğu söylenebilir. Çünkü günümüzde, dijital teknolojiler eğlence öğrenme ve diğer yaşamsal aktivitelerde yoğun bir şekilde kullanılmaktadır (Odabaşı, 2019). Eğlence kategorisinde daha çok erkek öğrencilerin metafor geliştirmesinin nedeninin dijital hikâyelerin bilgisayar ortamında oluşturulmasıyla ilgili olduğu söylenebilir.

Öğretmen adaylarının eğitim, teknoloji ve faydalı bulma kategorilerinde toplam 23 metafor oluşturdukları ve bu metaforların daha çok akıllı cep telefonu ve bilgisayarı olan öğrenciler tarafından oluşturulduğu görülmüştür. Öğretmen adaylarının dijital hikâyeleri, eğitim-öğretim süreci için yararlı buldukları söylenebilir. Alan yazının ve öğretim programlarının da vurguladığı öğrencilerin dijital yetkinlik kazanması ve 21. yüzyıl becerilerini edinmeleri, teknolojinin eğitim-öğretim sürecine entegrasyonu (MEB, 2019; BTK, 2018; Perkmen, ve Tezci, 2011) ifadeleriyle öğretmen adaylarının algılarının örtüştüğü söylenebilir.

Öğretmen adaylarının yaşam, evren ve gökyüzü, doğa ve yiyecek kategorilerinde toplam 30 metafor oluşturdukları görülmüştür. Teknoloji yaşamın bir parçasıdır ve günlük rutinlerin içerisinde yer almaktadır (Odabaşı, 2019). Buna bağlı olarak öğretmen adaylarının 21. yüzyıl yaşam becerilerine uzak olmadığı, teknolojiyi hayatın bir parçası olarak gördükleri söylenebilir.

Güvensiz bulma kategorisi altında oluşturulan 9 metafor bulunmaktadır. Bu durum dijital hikâyelerin bilgisayar ortamında oluşturulmasından kaynaklı öğretmen adaylarını endişelendirdiği söylenebilir. Bilgisayarda ve internette yüzde yüz güvenlik sağlamak ve güvenli bir ortam oluşturmak zor; ancak başlıca tedbirleri alarak yüksek düzeyde güvenlik sağlamak mümkündür (BTK, 2018). Bilgisayarda ve internette güvenliği sağlamanın bir yolu da dijital okuryazarlıktır. Buna bağlı olarak 21. yüzyıl becerileri arasında dikkat çeken becerilerden biri olan dijital okuryazarlık becerisinin (Günay ve Şişman, 2018) öğretmen, öğretmen adayları ve öğrenciler tarafından edinilmesini sağlayacak çalışmalar ve seminerler planlanmalı ve uygulanmalıdır.

$\mathrm{Bu}$ araştırmanın sonuçlarına bağlı olarak eğitim-öğretim sürecinde dijital hikâyelerin kullanımına yönelik saha çalışmalarına hız verilebilir. Dijital hikâye oluşturma süreçleriyle ilgili öğretmen, öğretmen adayı ve öğrencilere seminerler verilmesi planlanmalı ve uygulanmalıdır. Bununla birlikte dijital hikâye 
oluşturma sürecinde, bilgisayar ve internetin zararlı içeriklerinden kaçınmak için dijital okuryazarlık edinimine dair çalışmalar yapılarak öğretmen, öğretmen adayı ve öğrencilerin endişeleri önlenmelidir.

\section{Kaynakça}

Abou Shaaban, S. S. (2015). The effects of digital storytelling, storytelling and storyreading on enhancing palestinian ninth graders' paragraph writing skills. European Journal of Educational Studies, 7(1), 23-34.

Akbayır, S. (2007). Eğitim fakülteleri için cümle ve metin bilgisi. (Geliştirilmiş 5. Baskı). Ankara: Pegem Akademi.

Alexander, B. (2011). The new digital storytelling: creating narratives with new media. PRAEGER, ABC-CLIO: Santa Barbara, CA, US.

Arslan, M.M. ve Bayrakcı, M. (2006). Metaforik düşünme ve öğrenme yaklaşımının eğitim-öğretim açısından incelenmesi. Milli Ĕ̆ itim, 171, 100-108.

Aykaç, N. ve Çelik, Ö. (2014), Öğretmenlerin ve öğretmen adaylarının eğitim programına ilişkin metaforik algılarının karşllaştırılması. Eğitim ve Bilim, 39(173), 328-34.

Azizoğlu, N. İ. ve Okur, A. (2018). Türkçe öğretmeni adaylarının ekrandan okumaya yönelik metaforik alglları. Mehmet Akif Ersoy Üniversitesi Ĕ̆itim Fakültesi Dergisi, 46, 1-21.

Babacan, M. (2008). Yazıl ve sözlü anlatım (kompozisyon bilgileri). (Gözden Geçirilmiş 2. Baskı). İstanbul: $3 \mathrm{~F}$ Yayınevi.

Baki. Y. (2015). Dijital öykülerin altıncı sımıf öğrencilerinin yazma sürecine etkisi. Yayınlanmamış doktora tezi. Atatürk Üniversitesi, Eğitim Bilimleri Enstitüsü.

Banaszewski, T. M. (2005). Digital storytelling: supporting digital literacy in grades 4-12. Yayınlanmamış yüksek lisans tezi, Georgia Teknoloji Enstitüsü.

Barrett, H. (2009). Creating your digital story: a sequence of activities how to create simple digital stories. http://electronicportfolios.org/digistory/howto.html adresinden 20.10.2017 tarihinde erişilmiştir.

Bilgi Teknolojileri ve İletişim Kurumu, BTK. (2018). Bilgi teknolojileri ve internetin bilinçli, güvenli kullanımı. Ankara: Bilgi Teknolojileri ve İletişim Kurumu İnternet Daire Başkanlığı.

Bozpolat, E. (2015). Türkçe öğretmen adaylarının dört temel dil becerisine ilişkin metaforik algıları. Turkish Studies, International Periodical for the Languages, Literature and History of Turkish or Turkic, $10(11), 313-340$.

Ceran, D. (2015). Türkçe öğretmeni adaylarının Türkçe ders kitaplarına ilişkin metaforları. Uşak Üniversitesi Sosyal Bilimler Dergisi, 8(3), 121-140.

Ciğerci, F. M. (2015). İlkokul dördüncü sınff türkçe dersinde dinleme becerilerinin geliştirilmesinde dijital hikâyelerin kullanılması. Yayımlanmamış doktora tezi. Anadolu Üniversitesi Eğitim Bilimleri Enstitüsü.

Çıralı Sarıca, H. ve Koçak Usluel, Y. (2016). Eğitsel bağlamda dijital hikâye anlatımı: bir rubrik geliştirme çalışması. Eğitim Teknolojisi Kuram ve Uygulama, 6(2), 65-84.

Çıralı, H. (2014). Dijital hikâye anlatımını görsel bellek ve yazma becerisi üzerine etkisi. Yayımlanmamış yüksek lisans tezi. Hacettepe Üniversitesi, Eğitim Bilimleri Enstitüsü.

Dayan, G., ve Girmen, P. (2018). Türkçe eğitimi yazma sürecinde dijital öyküleme. Eğitimde Nitel Araştırmalar Dergisi, 6(3), 207-228.

Demirer, V. (2013). İlköğretimde e-öyküleme kullanımı ve etkileri. Yayınlanmamış doktora tezi. Necmettin Erbakan Üniversitesi, Eğitim Bilimleri Enstitüsü.

Dogan, B. (2007). Implementation of digital storytelling in the classroom by teachers trained in a digital storytelling workshop. Yayınlanmamış doktora tezi. Houston Üniversitesi, Eğitim Fakültesi. 
Doğan, D. M. (2005). Büyük Türkçe sözlük. İstanbul: Pınar.

Dündar, H. ve Karaca, E. T. (2013), Formasyon öğrencilerinin 'pedagojik formasyon programı'na ilişkin sahip oldukları metaforlar. Gazi Üniversitesi Endüstriyel Sanatlar Ĕ̆itim Fakültesi Dergisi, 30, 19-34.

Erdağı Toksun, S. (2019). Türkçe öğretmeni adaylarının okuma kavramına ilişkin metaforik algıları. Erzincan Üniversitesi Eğitim Fakültesi Dergisi, 21(2), 144-157.

Foley, L. M. (2013). Digital storytelling in primary-grade classrooms. Yayınlanmamış doktora tezi. Arizona State Üniversitesi.

Frazel, M. (2010). Digital storytelling: guide for educators. Eugene, OR: International Society for Technology in Education (ISTE). http://www.iste.org/images/excerpts/digsto-excerpt.pdf adresinden 07.09.2017 tarihinde erişilmiştir.

Gordon, C. (2011). Digital storytelling in the classroom: three case studies. Yayınlanmamış doktora tezi. Arizona Eyalet Üniversitesi.

Göçen, G. (2014). Dijital öyküleme yönteminin öğrencilerin akademik başarı ile öğrenme ve ders çalışma stratejilerine etkisi. Yayınlanmamış yüksek lisans tezi. Muğla Sıtkı Koçman Üniversitesi, Eğitim Bilimleri Enstitüsü.

Göçer, A. (2013). Türkçe öğretmeni adaylarının 'kültür dil ilişkisi'ne yönelik metaforik algıları. Turkish Studies - International Periodical For The Languages, Literature and History of Turkish or Turkic, 8(9), 253-263.

Günay, D. ve Şişman, B. (2018). Bilgi ve iletişim teknolojileri okuryazarlğı. A. D. Ö. ve Özçelik ve M. N. Tuğluk (Ed.), Eğitimde ve endüstride 21. yüzyll becerileri (s. 271-290). Ankara: Pegem Akademi.

Hett, K (2012). Technology-supported literacy in the classroom: using audiobooks and digital storytelling to enhance literacy instruction. Illinois Reading Council Journal, 4O(3), 3-13.

Hung, C. M., Hwang, G. J., ve Huang, I. (2012). A project-based digital storytelling approach for Improving students' learning motivation, problem-solving competence and learning achievement. Educational Technology \& Society, 15(4), 368-379.

Kahraman, Ö. (2013). Dijital hikâyecilik metoduyla hazırlanan öğretim materyallerinin öğrenme döngüsü giriş aşamasında kullanılmasının fizik dersi başarısı ve motivasyonu düzeyine etkisi. Yayınlanmamış doktora tezi. Balıkesir Üniversitesi, Fen Bilimleri Enstitüsü.

Karakoyun, F.(2014). Cevrimiçi ortamda oluşturulan dijital öyküleme etkinliklerine ilişkin öğretmen adaylar ve ilköğretim öğrencilerinin görüşlerinin incelenmesi. Yayınlanmamış doktora tezi. Anadolu Üniversitesi Eğitim Bilimleri Enstitüsü.

Karakuş, N. ve Kozçetin, K. (2016). Türkçe öğretmeni adaylarının okuma kavramına yönelik metaforik algılarının incelenmesi. Mehmet Akif Ersoy Üniversitesi Ĕ̆itim Fakültesi Dergisi, 40, 387-404.

Kaya, O. ve Tolu Tekiner, A. (2017). Investigating digital storytelling method in german as a foreign language teaching. Dil Dergisi, 168(1), 5-19.

MEB, (2019). Türkçe dersi öğretim programı ilkokul ve ortaokul 1, 2, 3, 4, 5, 6, 7 ve 8. simıflar. Ankara: MEB.

Odabaşı, F. (2019). Dijital yaşamda çocuk. (2. Baskı). Ankara: Pegem Akademi.

Perkmen, S., Tezci E. (2011). Giriş. Eğitimde teknoloji entegrasyonu. S. Perkmen ve E. Tezci (Editörler). s. 1-13. Ankara: Pegem A Yayıncllı.

Polatcan, F. (2018). Türkçe öğretmeni adaylarının bilgi ve kitap kavramlarına ilişkin metaforları. Sinop Üniversitesi Sosyal Bilimler Dergisi, 2(2), 113-126.

Robin, B. (2006). The educational uses of digital storytelling. in society for information. Technology \& Teacher Education International Conference. http://digitalstorytelling.coe.uh.edu/articles/Educ-Uses-DS.pdf adresinden $\quad$ 07.09.2017 tarihinde erişilmiştir. 
Saban, A. (2008). İlköğretim I. kademe öğretmen ve öğrencilerinin bilgi kavramına ilişkin sahip oldukları zihinsel imgeler. İlköğretim Online, 7(2), 421-455.

Seçkin Aydın, İ. ve Pehlivan, A. (2010). Türkçe öğretmeni adaylarının "öğretmen” ve "öğrenci" kavramlarına ilişkin kullandıkları metaforlar. Turkish Studies, International Periodical For the Languages, Literature and History of Turkish or Turkic, 5(3), 818-842.

Tatl, Z. ve Bayramoğlu A. (2015). Öğretmenlik uygulaması sürecinin dijital öyküler ile yansıtılması. Journal of Instructional Technologies \& Teacher Education, 4(2), 16-28.

Temizyürek, F. (2003). Türkçe öğretiminde çocuk edebiyatının önemi. Türklük Bilimi Araştırmaları, $13,161-167$.

Tiryaki, E. N. ve Demir, A. (2016). Türkçe öğretmeni adaylarının yazma becerisine yönelik metaforik alglları. Mustafa Kemal Üniversitesi Sosyal Bilimler Enstitüsü Dergisi, 13(33), 18-27.

Topçuoğlu Ünal, F. ve Tekin, M. T. (2013). Eleştirel yazmaya ilişkin türkçe öğretmeni adaylarının metaforik algıları. Turkish Studies International Periodical For The Languages, Literature and History of Turkish or Turkic, 8(13) 1595-1606.

Türk Dil Kurumu. (2011). Türkçe sözlük. (11. Baskı). Ankara: Türk Dil Kurumu Yayınları.

Yamaç, A. ve Ulusoy, M. (2016). The effect of digital storytelling in improving the third graders' writing skills. International Electronic Journal of Elementary Education, 9(1), 59-86.

Yamaç, A. (2015). İlkokul üçüncü sinıf öğrencilerinin yazma becerilerinin gelişiminde dijital hikâyelerin etkisi. Yayınlanmamış doktora tezi. Gazi Üniversitesi, Eğitim Bilimler Enstitüsü.

Yıldırım, A. ve Şimşek, H. (2013). Sosyal bilimlerde nitel araştırma yöntemleri. Ankara: Seçkin Yayıncilık.

Yılmaz, Y., Üstündağ, M. T., Güneş, E. ve Çalıșkan, G. (2017). Dijital hikâyeleme yöntemi ile etkili Türkçe öğretimi. Ĕgitim Teknolojisi Kuram ve Uygulama, 7(2), 254-275.

Yoon, T. (2013). Are you digitized? Ways to provide motivation for ells using digital storytelling. International Journal of Research Studies in Educational Technology, 2(1), 25-34.

Yüksel, P. (2011). Using digital storytelling in early childhood education: a phenomenological study of teachers" experiences. Yayınlanmamış doktora tezi. Orta Doğu Teknik Üniversitesi, Fen Bilimleri Enstitüsü.

Yürük, S. E. ve Atıcı, B. (2016). Dijital öykü temelli değerler eğitimi materyallerinin öğrencilerin değer kazanımına etkisi. Trakya Üniversitesi Eğitim Fakültesi Dergisi, 7(1), 56-74.

Walsh, B. ve Blewitt, P. (2006). The effect of questioning style during story book reading on novel vocabulary acquisition of preschoolers. Early Childhood Education Journal, 33(4), 273-278.

Wang, S. ve Zhan, H. (2010). Enhancing teaching and learning with digital storytelling. International Journal of Information and Communication Technology Education, 6(2), 76-87. 